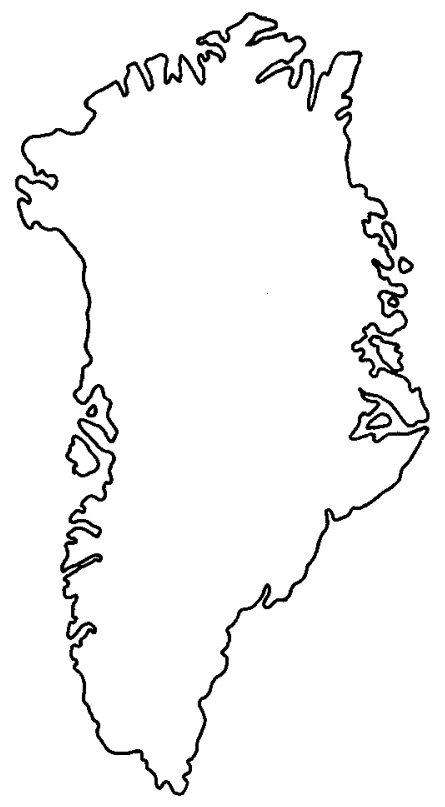

\title{
Early Ordovician trilobites from the Wandel Valley Formation, eastern North Greenland
}

\author{
R. A. Fortey
}

A small trilobite fauna is described from the Wandel Valley Formation of Kronprins Chriștian land, eastern North Greenland. It has a specific composition identical to the fauna from the Catoche Formation, western Newfoundland, which is typical of the shallow water bathyurid biofacies of the eastern part of the Ordovician Laurentian palaeocontinent. The fauna is of early Ordovician age, trilobite Zone $\mathrm{H}$, equivalent to the early Arenig.

R. A. F, British Museum (Natural History), Cromwell Road, London SW7 SBD, U. K.

The trilobites described in this report were collected from the Amdrup Member of the Wandel Valley Formation in western Kronprins Christian Land (fig. 1) by John S. Peel (Geological Survey of Greenland) who kindly made them available to the author for study. The Amdrup Member $(c .200 \mathrm{~m})$ is one of three members recognised within the Wandel Valley Formation in this area (Peel, 1982, 1985). An underlying Danmarks Fjord Member (10-12 $\mathrm{m}$ ) is discussed elsewhere in this report by Smith \& Peel (1986), while an overlying member (c. $200 \mathrm{~m}$ ) dominated by pale dolomites is un-named. The tripartite sub-division of the Wandel Valley Formation in Kronprins Christian Land can be compared with a similar sub-division into un-named members made by Christie \& Peel (1977) in the type area, southern Peary Land, to the north-west, but no precise correlation between the individual members is attempted.

The trilobites were collected at two localities near the western shore of Kronprins Christian Land, along the eastern side of Danmark Fjord (fig. 1). They are fragmentary, preserved in a grey pellet-limestone or fine intraformational conglomerate. GGU sample 274912 was collected about $50 \mathrm{~m}$ above the base of the member; GGU sample 274918 is from a nearby, uncontrolled locality within the member, but probably at about the same general stratigraphic level. Fortey \& Peel (1983) described the peculiar bathyurid trilobite $\mathrm{Ce}$ ratopeltis Poulsen, 1937 from near the base of the Amdrup Member at nearby Kap Holbæk (fig. 1).

The new fauna contains the following species: Petigurus nero (Billings, 1865), Bathyurellus abruptus Billings, 1865, Jeffersonia timon (Billings, 1865), Punka flabelliformis Fortey, 1979, Ischyrotoma anataphra Fortey, 1979, Benthamaspis conica Fortey, 1979, and Strotactinus sp. indet. Bathyurina Poulsen, 1937 is considered a subjective junior synonym of 


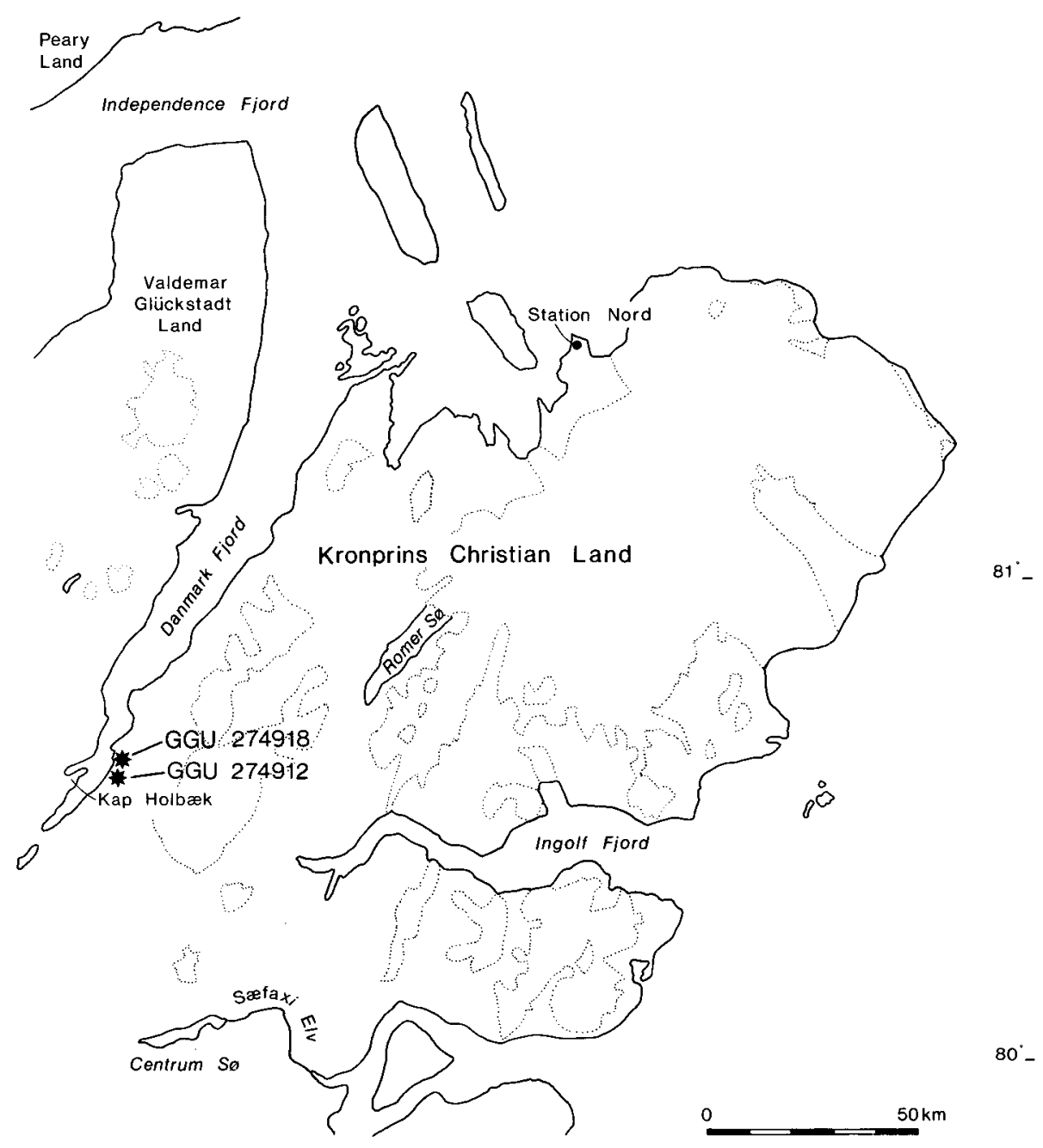

Fig. 1. The Danmark Fjord region of eastern North Greenland showing collection localities.

Jeffersonia Poulsen, 1927. The fauna provides a reliable correlation for the Amdrup Member of the Wandel Valley Formation, and confirms the palaeobiogeographic affinities of the Ordovician platform in Greenland.

\section{Age of the fauna}

There are no apparent differences in age between the two collected samples. All of the species positively identified from the Amdrup Member of the Wandel Valley Formation herein have been described from the lower part of the Catoche Formation, a division of the 
St George Group on the carbonate platform of western Newfoundland. This fauna was originally described by Billings (1865), and may be regarded as the type for the late 'Canadian' (now termed Ibexian) bathyurid trilobites of the Laurentian craton. Fortey (1979) redescribed this fauna, adding several additional taxa. The occurrence of the stratigraphically reliable pelagic trilobite Carolinites genacinaca nevadensis Hintze, 1953, together with the widespread Benthamaspis gibberula (Billings, 1865) in the Catoche Formation, indicated a correlation with trilobite Zone $\mathrm{H}$ of the standard trilobite zonation of Ross (1951) and Hintze (1953), based on sections in Utah and Nevada. The same fauna occurs in Spitsbergen, in the Kirtonryggen Formation (Fortey \& Bruton, 1973), where it underlies a rich graptolite fauna of early Arenig age (Cooper \& Fortey, 1982), which is late Bendigonian in terms of the 'Pacific Province' graptolitic standard. Whittington (1968, p. 50) recorded the Catoche fauna in boulders of the Cow Head Group underlain by graptolitic shales including Tetragraptus approximatus Nicholson, 1873. The Catoche fauna, and likewise that from the Amdrup Member, must therefore be of early Arenig age, and within all or part of the interval represented by the $T$. approximatus and $T$. fruticosus Biozones of the graptolitic standard.

\section{Palaeogeographic affinities of the fauna}

The Wandel Valley fauna is dominated by bathyurid trilobites, the eponymous family of what Whittington (1963) termed the Bathyurid Trilobite 'Province'. Rich bathyurid faunas are confined to shallow water limestones around Ordovician Laurentia, but some genera extend into north-east Siberia and even to the North China Platform in appropriate lithofacies, all following the Ordovician palaeoequator. The occurrence together of several bathyurid genera as a dominant element in a fauna is perhaps best regarded as an indicator of a particular biofacies, possibly the most inshore to which trilobites were adapted in the earlier Ordovician at palaeoequatorial latitudes. At the generic and even specific level very close matches with the present fauna are to be found in Ellesmere Island (Poulsen, 1946), East Greenland (Poulsen, 1937; Cowie \& Adams, 1957), Spitsbergen (Fortey \& Bruton, 1973), western Newfoundland (Fortey, 1979), north-west Scotland (see Petigurus nero below), Mingan Islands, Quebec (Twenhofel, 1938), New York and Vermont (Whitfield, 1886) and the Ozark Uplift, Missouri (Cullison, 1944). This distribution effectively describes the eastern perimeter of the Ordovician Laurentian continent, and can be matched by the distribution of other inshore faunal elements, such as the gastropod Ceratopea Ulrich, 1911, also occurring in the Amdrup Member of Kronprins Christian Land (Peel, 1980). Some of the trilobites extend into the western United States, but the faunas of early Ordovician age there (Ross, 1951; Hintze, 1953; Young, 1973) have many additional taxa besides bathyurids (and asaphids are often numerically dominant), and some of these (Shumardia Billings, 1862, 'Geragnostus' Howell, 1935) are more usually associated with deeper water, open shelf habitats (cf. Fortey, 1975). The same comments apply to the Nunatami Formation of western North Greenland (Poulsen, 1927). Nonetheless it is notable that a single species, Benthamaspis gibberula Billings, is distributed between the limits of this total range (Ellesmere Island, Spitsbergen, Newfoundland, Utah). The evidence from the new fauna serves to strengthen the coherence of the bathyurid biofacies in relation to its palaeolatitudinal and facies requirements. 


\section{Systematic notes}

Since the trilobites were described from numerous specimens by the author in 1979 it is not necessary to repeat detailed descriptions here; comparative discussion is sufficient. They are treated in the same order as in the Treatise on Invertebrate Paleontology (Moore, 1959).

Family Bathyuridae Walcott, 1886

Subfamily Bathyurinae Walcott, 1886

Genus Jeffersonia Poulsen, 1937

Type species. Jeffersonia exterminata Poulsen, 1937, by monotypy.

Remarks. Fortey (1979) demonstrated the association of the pygidium described by Billings (1865) as Bathyurus timon with a cranidium resembling that of the type species of Bathyurina Poulsen, 1937. This species, B. megalops, was based on a cranidium from East Greenland which had no pygidium assigned to it by Poulsen. The pygidium from the Wandel Valley Formation is identical to that of Billings' species. However, Poulsen had earlier (1927) described the type species of Jeffersonia from western North Greenland, this time from the pygidium alone, basing his erection of the genus on the supposition that $\mathrm{E}$. O. Ulrich would shortly describe other species from the Jefferson City Formation of Missouri, a publication which never appeared. Cullison (1944) subsequently assigned several species to Jeffersonia from this region, one of which (Fortey, 1979, p. 74) is exceedingly like the type species of Bathyurina, and B. timon. Others, for example $J$. crassimarginata (Cullison, 1944, Pl. 35, fig. 15), have pygidia closely similar to the type species of Jeffersonia from Greenland. The differences between the $B$. timon type of pygidium and that of $J$. exterminata are not considerable: the latter is the more transverse, with a slightly broader border, while the former has a third pair of pleural furrows, and deeper dorsal furrows generally. Since the expression of dorsal furrows and width of pygidial borders is variable within other bathyurid genera, it becomes difficult to sustain Jeffersonia and Bathyurina as separate genera, and they are regarded as subjective synonyms, Jeffersonia taking priority. Cranidia of Jeffersonia crassicaudata and Bathyurina megalops are alike, other than the glabella overhanging the border in the latter. Final clarification of the status of these genera must await the discovery of a pygidium of the type species of Bathyurina from East Greenland, and a cranidium of the type species of Jeffersonia from western North Greenland.

\section{Jeffersonia timon (Billings, 1865) \\ Plate 1, fig. 6}

Material. Pygidium, MGUH 17.091 from GGU sample 274918.

Discussion. The pygidium figured here is mostly exfoliated, in which condition the pleural furrows are particularly deep and wide. The Wandel Valley specimen is identical to an internal mould from the Catoche Formation figured by Fortey (1979, P1. 20, fig. 10), which has a slightly narrower pygidial border than the type specimen. Of other species the most similar pygidium is probably that of $J$. producta Cullison, 1944, which, however, has a much wider border and prominent mid-axial tubercles. 
Genus Petigurus Raymond, 1913

Type species. Bathyurus nero Billings, 1865, by monotypy.

Petigurus nero Billings, 1865

Plate 2, figs 1,3,4

Figured material. Cranidium, MGUH 17.092, pygidium, MGUH 17.093, free cheek, MGUH 17.094. All from GGU sample 274912.

Additional material. Pygidium, GGU sample 274912.

Discussion. The type species from western Newfoundland was redescribed by the present writer in 1979. I noted there that $P$. nero is distinguished from other species assigned to the genus, especially $P$. groenlandicus Poulsen, 1937 from East Greenland, in having incomplete pygidial interpleural furrows which are only present towards the pygidial margin (and often only clearly developed on the first two segments). Pygidia from the Wandel Valley Formation (Pl. 2, fig. 3) are clearly of this type. The cranidium (Pl. 2, fig. 1) has somewhat smaller tubercles than that figured by Fortey (1979, Pl. 29, fig. 2) but is not different from that shown on his Pl. 29, fig. 3; there is evidently some intraspecific variation in this character. A record of Petigurus from the Durness Limestone of north-west Scotland (Stubblefield, 1939) can be confirmed; examination of a cast of this pygidium in the British Geological Survey also suggests $P$. nero. There is also a free cheek in the collections of the British Museum (Natural History) from Durness, which is identical to that of Jeffersonia timon.

\section{Subfamily Bathyurellinae Hupé, 1953 Genus Bathyurellus Billings, 1865}

Type species. Bathyurellus abruptus Billings, 1865, designated Raymond (1905).

\section{Bathyurellus abruptus Billings, 1865 \\ Plate 2, figs 2,6,7}

Figured material. Cranidium, MGUH 17.095, and pygidium, MGUH 17.097, from GGU sample 274912. Pygidium, MGUH 17.096, from GGU sample 274918.

Discussion. The cranidium is not complete, but fragments of exoskeleton adhering to the glabella and occipital ring show terrace lines. $B$. abruptus cranidia are distinguished from those of $B$. platypus Fortey, 1979, in having the glabella with sculpture of terrace lines rather than pits. $B$. platypus succeeds $B$. abruptus in the Catoche Formation, western Newfoundland. The pygidium shows a flattened, rather than downsloping postaxial field, which again is like $B$. abruptus, and unlike B. platypus. Another pygidium (Pl. 2, fig. 7) is preserved from the underside, and shows the broad doublure with numerous terrace lines, and a postaxial ridge which is characteristic of the genus. Most of the species previously referred to Bathyurellus would now be placed in Punka (below); Bathyurellus occurs in Utah, western Newfoundland and Spitsbergen, and is definitely established from Greenland in this paper 
for the first time, although the author noted $(1979$, p. 90$)$ that the pygidium attributed to $B$. teicherti by Poulsen (1937) may prove to belong within Bathyurellus s.s. also.

\section{Genus Punka Fortey, 1979}

Type species. Bathyurellus nitidus Billings, 1865, original designation.

Remarks. The genus Punka was erected to accommodate those bathyurellines (formerly placed in Bathyurellus) with wide fan-shaped pygidia; the type and other species of Bathyurellus in the sense used here have distinctive, spatulate pygidia with unfurrowed pleural fields behind the anterior segment.

\section{Punka flabelliformis Fortey, 1979 \\ Plate 1, figs 2,3}

Figured material. Cranidium, MGUH 17.088, and pygidium, MGUH 17.089, from GGU sample 274912.

Discussion. Although the material is somewhat fragmentary, it is clearly conspecific with the species from western Newfoundland. The pygidium is especially distinctive, with deep and slightly curved pleural furrows close to the axis, which shallow abruptly at the border but continue faintly towards the margin (cf. Pl. 1, fig. 7 with Fortey, 1979, Pl. 33, fig. 1). The species also occurs in the Kirtonryggen Formation, northern Ny Friesland, Spitsbergen (Fortey \& Bruton, 1973).

Family Lecanopygidae Lochman, 1953

Genus Benthamaspis Poulsen, 1946

Type species. Benthamaspis problematica Poulsen, 1946 (probably the same species as B. gibberula (Billings, 1865) see Fortey, 1979, p. 101).

Benthamaspis conica Fortey, 1979

Plate 1, figs 1,2

Figured material. Cranidium, MGUH 17.087, from GGU sample 274912.

Discussion. Two very similar Benthamaspis species were described from western Newfoundland: B. gibberula (Billings, 1865) and B. conica Fortey, 1979. The important distinction between them was stated to be that in $B$. gibberula the preglabellar furrow was effaced, whereas the same furrow in $B$. conica was distinctly defined. The anterior view of the cranidium from the Wandel Valley Formation (P1. 1, fig. 2) shows the definition of this furrow across the mid-line, and the Greenland specimen is accordingly placed in $B$. conica. Most Newfoundland specimens of $B$. conica have a long (tr.) occipital furrow, extending most of the way across the glabella, whereas most $B$. gibberula have a short median section of this furrow only. In this character, the Greenland specimen is more like $B$. gibberula than $B$. 
conica. However, since the development of the occipital furrow is variable even within $B$. gibberula (Fortey, 1979, Pl. 34, figs 1,5,7), the preglabellar furrow is preferred as a character to determine the species. $B$. conica is reported as underlying $B$. gibberula in Newfoundland.

Family Dimeropygidae Hupé, 1953

Genus Ischyrotoma Raymond, 1925

Type species. Ischyrotoma twenhofeli Raymond, 1925, original designation.

\author{
Ischyrotoma anataphra Fortey, 1979 \\ Plate 1, figs 4,5
}

Figured material. Cephalon, largely exfoliated, MGUH 17.090, from GGU sample 274912.

Discussion. This species of Ischyrotoma has a distinctive specific character that readily separates it from others in the genus: the cranidial portion of the cephalic border furrow is extremely shallow compared with the furrows defining the borders of the free cheeks. The Greenland specimen clearly shows this character (Pl. 1, fig. 5), and the specific identification is well founded. The fact that the cephalon is found here with cheeks in place, whereas the other material is disarticulated, the same being true of the Catoche Formation occurrences, suggests that the facial sutures were probably not functional in this species, at least later in ontogeny, even though they are visible on the specimen.

Family Pliomeridae Raymond, 1913

Subfamily Cybelopsinae Fortey, 1979

Genus Strotactinus Bradley, 1925

Type species. Amphion insularis Billings, 1861, original designation.

Strotactinus sp. indet.

Plate 2, fig. 5

Figured material. Cranidium, MGUH 17.098, from GGU sample 274912.

Discussion. An incomplete cranidium is not enough for specific determination, especially in a genus in which pygidial characters are taxonomically important. It is, however, similar to that attributed to $S$. insularis (Billings, 1865) (Fortey, 1979, Pl. 37, figs 1,4,7), and given the other similarities between the fauna from western Newfoundland and that of the Wandel Valley Formation, it is possible to attribute the cranidium to Strotactinus, under open nomenclature.

Acknowledgements. I thank Dr J. S. Peel for bringing my attention to the material described here and for providing fig. 1. The Geological Survey of Greenland provided support in Copenhagen. MGUH denotes the type collection of the Geological Museum, Copenhagen. 


\section{References}

Billings, E. 1865: Palaeozoic fossils. Volume 1. Containing descriptions and figures of new or little known species of organic remains from the Silurian rocks. 1861-5. Geol. Surv. Can., 462 pp.

Christie, R. L. \& Peel, J. S. 1977: Cambrian-Silurian stratigraphy of Børglum Elv, eastern North Greenland. Rapp. Grønlands geol. Unders. 82, 48 pp.

Cooper, R. A. \& Fortey, R. A. 1982: The Ordovician graptolites of Spitsbergen. Bull. Br. Mus. nat. Hist. Geol. 36, 157-302.

Cowie, J. W. \& Adams, P. J. 1957: The geology of the Cambro-Ordovician rocks of central East Greenland. Part 1. Stratigraphy and structure. Meddr Grønland 153(1), $193 \mathrm{pp}$.

Cullison, J. S. 1944: The stratigraphy of some Lower Ordovician formations of the Ozark Uplift. Bull. Univ. Missouri School Mines Metall. 15, 1-115.

Fortey, R. A. 1975: Early Ordovician trilobite communities. Fossils and Strata 4, 331-352.

Fortey, R. A. 1979: Early Ordovician trilobites from the Catoche Formation (St. George Group), western Newfoundland. Bull. geol. Surv. Can. 321, 61-114.

Fortey, R. A. \& Bruton, D. L. 1973: Cambrian-Ordovician rocks adjacent to Hinlopenstretet, North Ny Friesland, Spitsbergen. Bull. geol. Soc. Am. 84, 2227-2242.

Fortey, R. A. \& Peel, J. S. 1983: The anomalous bathyurid trilobite Ceratopeltis and its homoeomorphs. Spec. Pap. Palaeontology 30, 51-57.

Hintze, L. F. 1953: Lower Ordovician trilobites from western Utah and eastern Nevada. Bull. Utah Geol. Miner. Surv. 48, 1-249.

Moore, R. C. (edit.) 1959: Treatise on Invertebrate Paleontology. Part 0. Arthropoda 1. Lawrence: Geol. Soc. Am. and Kansas U.P., 550 pp.

Peel, J. S. 1980: Ceratopea billingsi (Gastropoda) from the Early Ordovician of Kronprins Christian Land, eastern North Greenland. Rapp. Grønlands geol. Unders. 101, 68 (only).

Peel, J. S. 1982: The Lower Palaeozoic of Greenland. Proc. IIIrd Arctic Symposium Calgary 1981. Mem. Can. Soc. Petrol. Geol. 8, 309-330.

Peel, J. S. 1985: Cambrian-Silurian platform stratigraphy of eastern North Greenland. In Gee, D. G. \& Sturt, B. A. (edit.) The Caledonide Orogen: Scandinavia and related areas, 1077-1094. London: John Wiley \& Sons.

Poulsen, C. 1927: The Cambrian, Ozarkian and Canadian faunas of Northwest Greenland. Meddr Grønland 70, 233-343.

Poulsen, C. 1937: On the lower Ordovician faunas of East Greenland. Meddr Grønland 119(3), 72 pp.

Poulsen, C. 1946: Notes on the Cambro-Ordovician fossils collected by the Oxford University Ellesmereland Expedition. J. geol. Soc. London 102, 299-337.

Raymond, P. E. 1905: The trilobites of the Chazy Limestone. Annals Carnegie Mus. 3, 328-386.

Ross, R. J. Jr. 1951: Stratigraphy of the Garden City Formation in northeastern Utah, and its trilobite faunas. Bull. Peabody Mus. Nat. Hist. 6, 1-161.

Smith, M. P. \& Peel, J. S. 1986: The age of the Danmarks Fjord Member, eastern North Greenland. Rapp. Grønlands geol. Unders. 132.

Stubblefield, C. J. 1939: Some aspects of the distribution and migration of trilobites in the British Lower Palaeozoic faunas. Geol. Mag. 76, 49-72.

Twenhofel, W. H. 1938: Geology and paleontology of the Mingan Islands, Quebec. Spec. Pap. geol. Soc. Am. 11, 132 pp.

Whitfield, R. P. 1886: Notice of the geological investigations along the eastern shore of Lake Champlain....\&c. Bull. Am. Mus. nat. Hist. 1, 293-345.

Whittington, H. B. 1963: Middle Ordovician trilobites from Lower Head, western Newfoundland. Bull. Mus. comp. Zool. Harv. 129, 118 pp.

Whittington, H. B. 1968: Zonation and correlation of Canadian and early Mohawkian Series. In Zen, E.-A., White, W. S. \& Hadley, J. B. (edit.) Studies of Appalachian geology, northern and maritime, 49-60. New York: Wiley Interscience.

Young, G. E. 1973: An Ordovician (Arenigian) trilobite faunule of great diversity from the Ibex area, western Utah. Geol. Stud. Brigham Young Univ. 20, 91-115. 


\section{Plate 1}

From GGU sample 274912 unless stated

Figs 1,2. Benthamaspis conica Fortey, 1979, MGUH 17.081, cranidium in dorsal and anterior views, the latter showing the preglabellar furrow, both $\times 8$.

Figs 3,7. Punka flabelliformis Fortey, 1979. 3, MGUH 17:088, incomplete cranidium, $\times 8$, dorsal view; 7, MGUH 17.089, incomplete pygidium, $\times 4$.

Figs 4,5. Ischyrotoma anataphra Fortey, 1979, MGUH 17.090, partly exfoliated cephalon in dorsal and oblique views, latter showing effacement of cranidial anterior border furrow, $\times 8$.

Fig. 6. Jeffersonia timon (Billings, 1865), MGUH 17.091 from GGU sample 274918, pygidium, $\times$ 4; largely exfoliated, left hand side cannot be prepared as it lies beneath a pygidium Bathyurellus abruptus, (Pl. 2, fig. 6).

\section{Plate 2}

From GGU sample 274912 unless stated

Figs 1,3,4. Petigurus nero (Billings, 1865). 1, MGUH 17.092, internal mould of cranidium; 3, MGUH 17.093, pygidium, $\times 4$; 4, MGUH 17094, free cheek, plan view, $\times 4$; all specimens largely exfoliated.

Figs 2,6,7. Bathyurellus abruptus Billings, 1865. 2, MGUH 17.095, incomplete cranidium, $\times 6$; 6 , MGUH 17.096 from GGU sample 274918, pygidium, dorsal view, $\times$ 4; 7, MGUH 17.097, pygidium preserved from underside showing doublure and sculpture, $\times 5$.

Fig. 5. Strotactinus sp. indet, , MGUH 17.098, fragmentary cranidium, $\times 4$. 
Plate 1
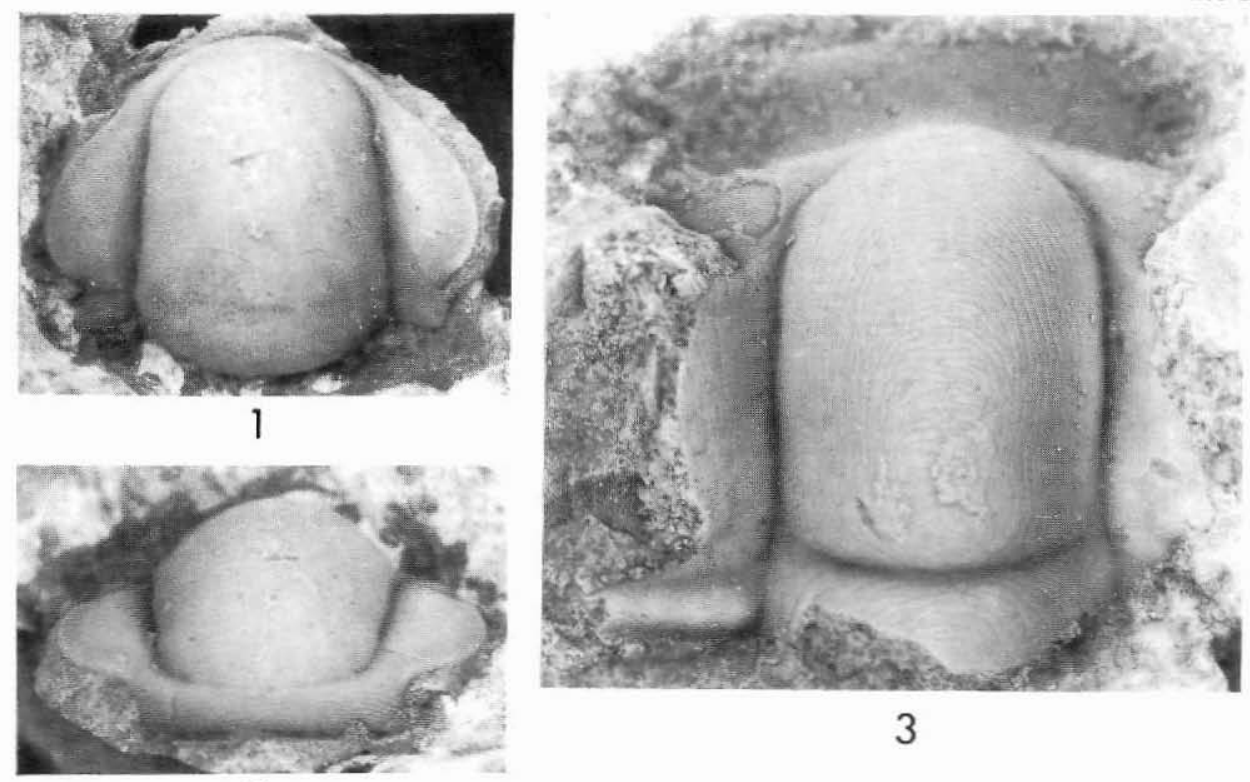

3

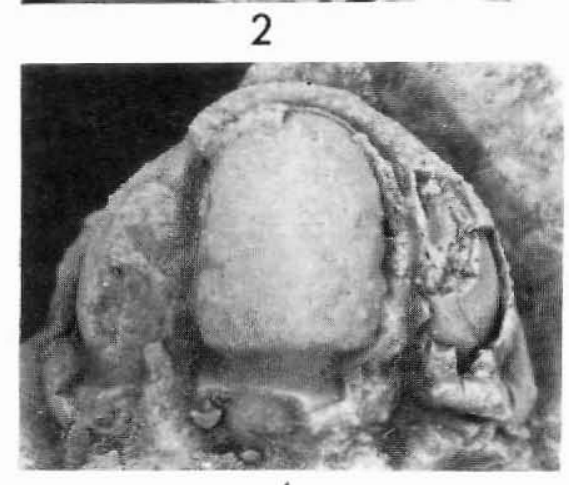

4

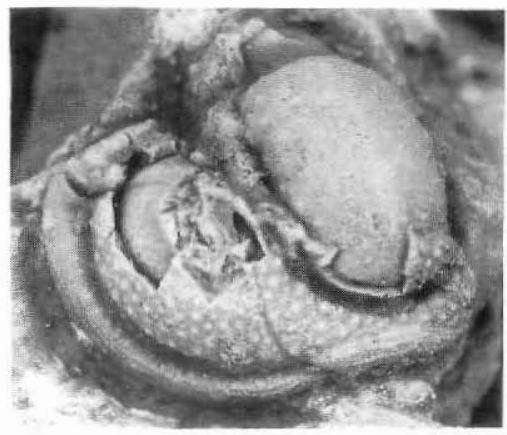

5
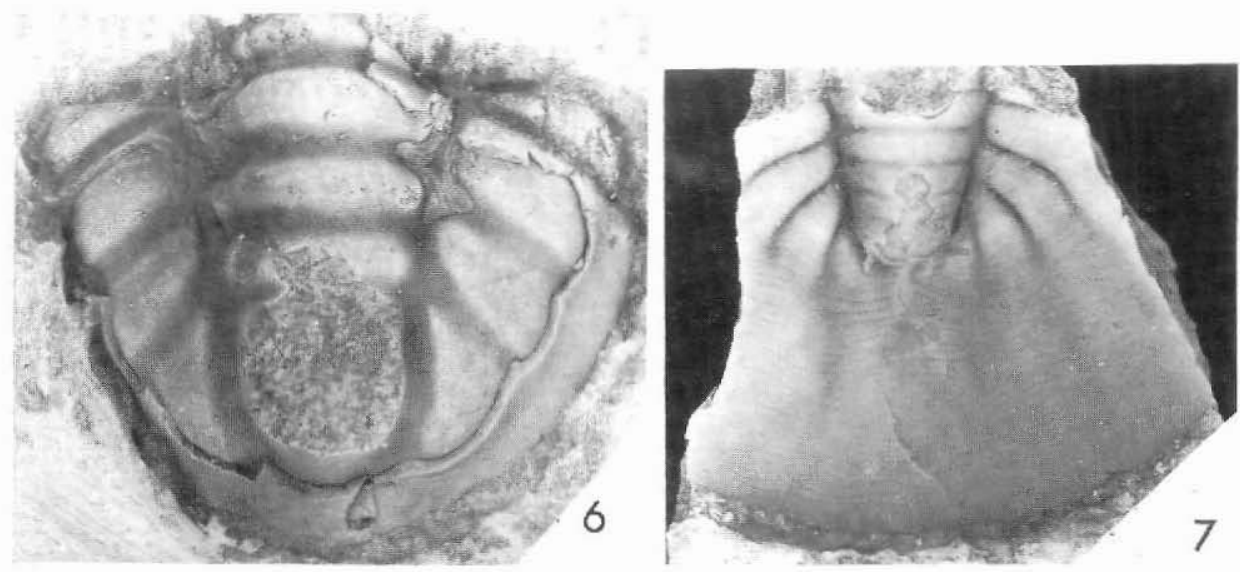
Plate 2
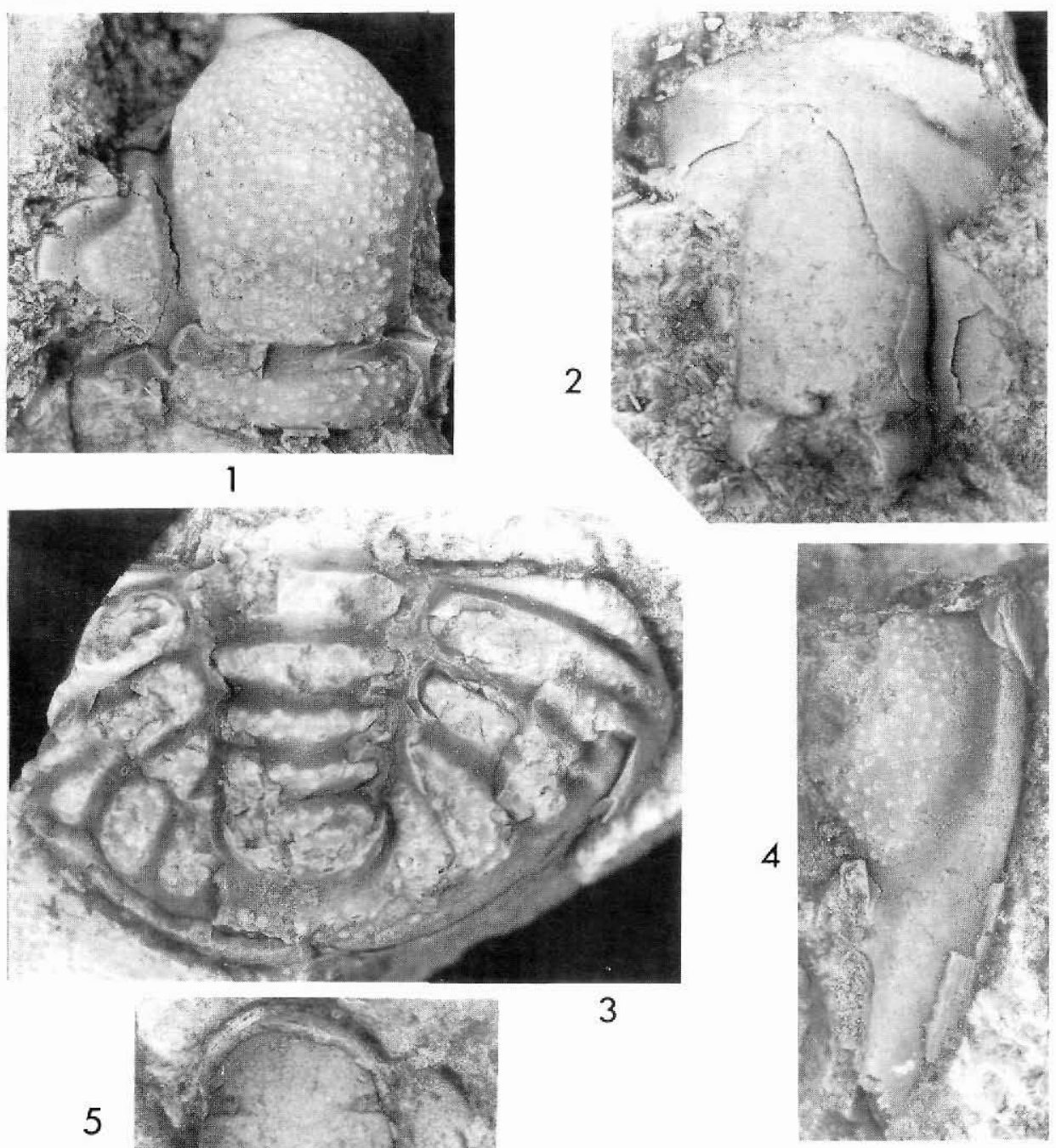

5

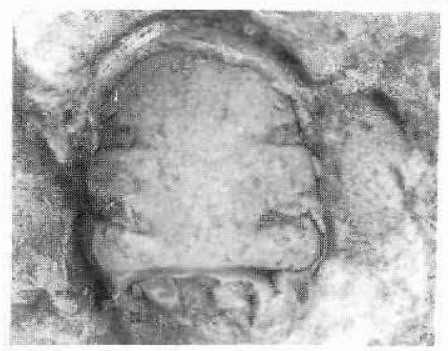

3

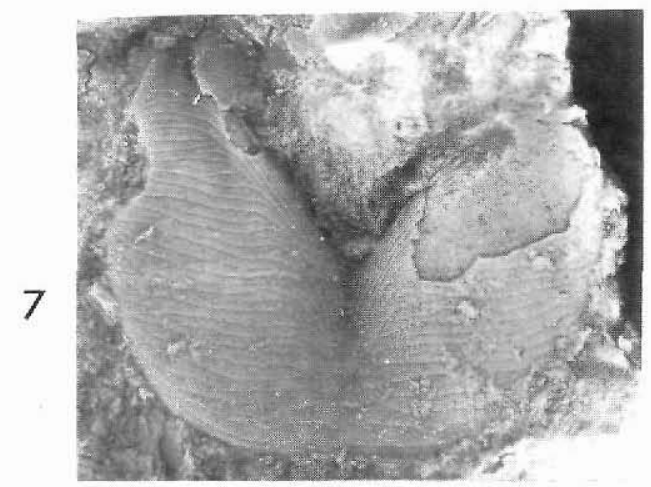

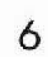

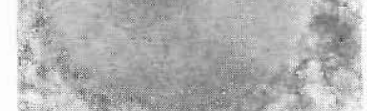

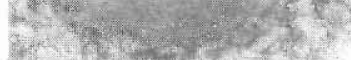

3 